Panigrahi, Hemanta Kumar / Int. J. Res. Ayurveda Pharm. 4(5), Sep - Oct 2013

Review Article

www.ijrap.net

\title{
ORIGIN OF SURGERY: A HISTORY OF EXPLORATION OF PLASTIC AND RECONSTRUCTIVE SURGERY
}

Panigrahi, Hemanta Kumar*

Ayurveda Central Research Institute, Punjabi Bagh West, New Delhi, India

Received on: 07/08/13 Revised on: 20/08/13 Accepted on: 18/09/13

\author{
*Corresponding author \\ E-mail: drhemanta@sify.com \\ DOI: $10.7897 / 2277-4343.04501$ \\ Published by Moksha Publishing House. Website www.mokshaph.com \\ All rights reserved.
}

\section{ABSTRACT}

The Sushruta Samhita, Charaka samhita and Astanga sangraha are the tri compendia of Ayurveda encompassing all the aspects of Ayurveda. Plastic surgery (Sandhana karma) is a very old branch of surgery described since Vedic era. Almost all the Samhitas described about the methods of Sandhana Karma (Plastic and reconstructive surgery). Now a day the world recognizes the pioneering nature of Sushruta's plastic and reconstructive surgery and Sushruta is regarded as Father of Plastic surgery. The plastic operations of ear (otoplasty) and Rhinoplasty (Plastic Surgery of nose) are described in the $16^{\text {th }}$ Chapter of first book (Sutrasthan) of the compendium. First methods are described for piercing the earlobes of an infant which still is a widespread practice in India. Sushruta has described 15 methods of joining these cup-up ear lobes. For this plastic operation called karna bedha, a piece of skin was taken from the cheek, turned back, and suitably stitches the lobules. Sushruta has also described Rhinoplasty (Nasa Sandhana). Portion of the nose to be covered should be first measured with a leaf. Then a piece of skin of the required size should be dissected from the living skin of the cheek and turned back to cover the nose, keeping a small pedicle attaches to the cheek. The part of nose to which the skin is to be attached should be made raw by cutting of the nasal stump with a knife. The surgeon then should place the skin on the nose and stitch the two parts swiftly, keeping the skin properly elevated by inserting two tubes of eranda (castor oil plant) in each part of nostril so that the new nose gets proper shape. It should then be sprinkled with a powder composed of liquorices, red sandalwood, and barberry plant. Finally it should be covered with cotton and clean sesame oil should be constantly applied to it. Sushruta also mentioned the reconstruction of the broken lip and hare-lip (ostha Sandhana).These descriptions are brief in nature in comparison to Karnasandha (Plastic surgery of ear). This paper describes the historical perspective of Sandhana karma (Plastic surgery) described in Ayurveda.

Keyword: Sandhana karma, Nasa sandha, Osthasandhana, Plastic surgery, Rhinoplasty.

\section{INTRODUCTION}

Plastic Surgery is a specialized branch of surgery devoted to the treatment of deformities of the face and other parts of the body. Plastic surgery is mainly concerned with the integument and often of the underlying skeletal frame work. Plastic surgery has little to do with plastic, the synthetic substances so common today. The term plastic derived from the Greek word plastikos, means to mould or shape. The importance of plastic surgery is to restore the appearance and function of parts of the body destroyed or, damaged by disease or injury. Contrary to Popular belief plastic or reconstructive surgery is not merely cosmetic surgery but an important discipline that aims at correcting all sorts of physical deformities. ${ }^{1}$ The Sushruta Samhita, Charaka Samhita and Astanga sangraha are the tri compendia of Ayurveda encompassing all the aspects of Ayurveda. The Sushruta Samhita, a work of the early century of Christian era, mainly deals with surgical knowledge. It represents faithfully the school of surgery which made significant contributions to principles and techniques of surgery which are surprisingly applicable even in modern era. It presents the status of ancient Indian surgery comprehensively and as such is in great demand among scholars all over the world. The plastic operations of otoplasty (Plastic Surgery of ear) and Rhinoplasty (Plastic Surgery of nose) are described in the $16^{\text {th }}$ Chapter of first book (Sutra sthan) of compendium. First methods are described for piercing the earlobes of an infant which still is a widespread practice in India. Often these earlobes, due to the use of heavy ornaments, get considerably expanded and ultimately sunder. Sushruta has described 15 methods of joining these cup-up ear lobes. For these plastic operations called karna bedha, a piece of skin was taken from the cheek, turned back, and suitably stitches the lobules. Further treatment of operation, periodic dressing of the wound and use of various ointments is elaborately described. Similarly Sushruta has described Rhinoplasty very clearly.

\section{Historical Perspective}

Plastic Surgery is one of the oldest forms of surgery. Reconstructive plastic surgical procedures were performed in ancient India, where the practitioners of art carried on a flourishing trade because of the custom of punishing criminal and marking prisoners of wars and unfaithful wives by amputation of nose. These procedures of plastic surgery were described in the writings of Sushruta ( 800 B.C.). The exact original plastic surgery of the nose is obscure, but India supplied many subjects for replacement because of a form of punishment of cutting of the nose. The method in India was a direct forehead flap with no special reference to providing a living. One report of the method stated however, that the "operation is always successful" and the nose looks as well as the natural one.

\section{Vedic Period}

The birth of Plastic Surgery was from India. If we look into the Vedic Rituals we find the knowledge of Plastic and Reconstructive Surgery was known to Bramha, Vishnu, Maheswar, Indra, Dhanwantari, Dadhichi and 
Ashwanikumaras. In Rigved (1-158, 4-6), Dakshya cut the head and trunk of Rishi Chyavan. Then Ashwani Kumaras perform the first Plastic Operation and give life to Rishi Chyavan. At the time of war when enemies cut the leg of Bispala, wife of King Khela, Ashwani Kumaras transplant the leg by a leg made with iron (Rigveda 1116.95). In Rig-Veda (1-117-19) the description about Micro Surgery is found ${ }^{2}$. The part of body lost by Rishi Atri was re-joined by Ashwani Kumara. The body of Rishi Shyaba was cut into three parts by his enemy. Immediately Ashwani Kumaras rejoin the part and gives his life back (Rig-Veda 1-117-14). Besides this hetero transplantation was also performed by Ashwani Kumaras during vedic period. Ashwani Kumaras interested to learn Madhu Vidya from Dadhyancha. So Ashwani Kumara cut the head of Dadhyancha; kept separately. Then transplant the head of a horse and learn Madhu Vidya from the horse. After learning Madhu Vidya again they separate the head of horse from Rishi Dadhyancha and transplant his own head (Rig-Veda 1-116-13/9-117-17). In Padmapuran the written evidence of transplantation is also found. In Padmapuran (2-66/212-215) Ashwani Kumaras transplant the head of Yagnya. Bhairav cut the head of Bramha and Dadhichi. In this condition Ashwani Kumaras rejoined their heads with their respective bodies. Shivji cut the head of Ganesh and after the request of Mata Parvati Shivji transplant the head of an Elephant. This is a typical example of hetero transplantation.

\section{Samhita Period}

Written evidence cites medical treatment for facial injuries more than 4,000 years ago. Physicians in ancient India utilizing the skin graft for reconstructive purpose as early as 800 B.C. Description regarding the methods of transplantation was first found in Sushruta Samhita (600 B.C.). At that time one of the royal punishments was to cut away the ear lobule, nose etc. and the victims resorted to the surgeons help for correction. Indian surgeons have applied their technique for correcting such deformity by shifting the skin flap to reform the nose and ear lobule. They also appreciated the importance of wound healing for a successful Plastic Operation. Although Indians acquired proficiency in surgery as a whole. Its revival can be traced to a report from India in 1974, and illustrated accounts of Rhinoplastic Operation upon one Cowasjee, a bullock driver, was published in Gentleman's Magazine in England. However the basic principles lead by Sushruta was even now-a-days followed by Modern Plastic Surgeons. Then due to the impact of Buddha and Jain Dharm, the surgery branch slowly lost their dignity. Peoples at that time were not interested in surgery. So the knowledge of Plastic and Reconstructive surgery was diminished during this period. On the other hand this knowledge of Indians slowly spreads into the Arab Countries by the businessmen. From them the Europeans gain the knowledge of Plastic Surgery. In $14^{\text {th }}$ to $15^{\text {th }}$ Century the knowledge of Plastic and Reconstructive Surgery was known to Branco Family in Sicily. They perform the Rhinoplastic Surgery by taking the flaps from the hand. In $16^{\text {th }}$ Century Winco Family in Italy was famous for Plastic Operation. In $17^{\text {th }}$ Century this surgery lost its dignity due to restriction of surgery in Church.
Peoples forgot about the Plastic Operation. Re-birth of Modern Plastic Operation took place again in India. In 1814, first Reconstructive surgery was done by an English Surgeon. In 1818, Indian and Italian methods of Reconstruction of nose were performed in Berlin. In 1823, the first skin Grafting was done by Bonger. Boren in 1840 was done extensive research work on this. However the credit of first established skin grafting was goes to Riverdeen in 1869 and Olears in 1872 and Gyers in 1874. But the developed and sophisticated Plastic Operation was performed during the First World War (1914-1918). Giliese an ENT Surgeon has done extensive work on reconstruction of nose and ear etc. So Gillise is known as Father of Modern Plastic Surgery.

\section{Concept of Plastic and Reconstructive Surgery in Ayurveda}

The most ancient literatures of the world i.e. Rig-Veda is full of example of various surgical, plastic surgical, orthopedic and ophthalmological operations done by the Dev Vaidya - Ashvini Kumars. Ashwini Kumars operated and rehabilitated the leg of vishalpa wife of king khel which was cut down by the enemy in war. According to the 'Upanishad' Ashwini Kumars also operated and repaired the excised head of Yaganya by Rudra. They operated the eyes of Reejashva. They also implanted the teeth of phushna in his edentulous mouth. From Ashwani Kumars this of knowledge of Ayurvedic science descended. Samhita, the most ancient and authentic literature on plastic surgery, has described elaborately the plastic surgical operations for deformed, cut ears, lobules, Rhinoplastic operations to repair deformed nose, and corrective plastic surgical operations of cleft lip, cleft palate and injured lip in Samhita chapter 16 of Sutra Sthana (First book of the compendium) ${ }^{3}$. Flap technique of skin grafts described in Samhita is the most successful technique of plastic surgery even now a day.

\section{Sushruta's Description}

If a person without ear lobule comes to the surgeon (Vaidya), then the skilled surgeon should reconstruct the ear lobule by taking a flap of skin from the cheek region; with a slip attached to the donor site ${ }^{4}$. The major aim of keeping the skin flap attached to the donor site with a slip is to maintain the adequate blood perfusion for prompt healing without any complications and the organ is vitalized with sensations and heals very soon. This technique is used in the same manner even now a day.

\section{Operative Technique Used To Repair Ear Lobule}

For reconstruction of injured ear lobule there are fifteen methods ${ }^{5}$ e.g.

1. Nemi Sandhanaka

2. Utpala bhedyaka

3. Valloorka

4. Aasangima

5. GandKarna

6. Aaharya

7. Nirvedhima

8. Vyayojima

9. Kapata Sandhika

10. Ardha Kapata Sandhika 
All the above 10 types of operation gives best result and usually successful. Remaining 5 types are generally unsuccessful technique. These are -

1. Sankhshipta

2. Heen Karna

3. Valli Karna

4. Kakaushthka.

5. Yasti Karna

\section{Methods of Otoplasty}

Similarly Sushruta in his first compendium chapter 16 and verse 17 described about the procedure of otoplasty ${ }^{6}$.

1. Nemi Sandhanak: When both fragments of ear lobule are heavy and large in surface and also equal in shape and size then Nemi Sandhanak type of otoplasty is indicated

2. Utpala Bhedyaka: When the cut ear lobule is equal in shape and size, large around then utpala bhedyaka type of otoplasty should be performed.

3. Balluraka: Balluraka bandha is indicated when both fragment of cut ear lobules are small, round and equal in shape and size.

4. Aasangima: When proximal part of cut ear lobule is larger than Aasangima type of otoplasty should be done.

5. Gandhakarna: Similarly when distal fragment of cut ear lobule is larger than this type of otoplasty is indicated

6. Nirvedhima: In case, both the fragments of ear lobule are absent, then Nirvedhima type of otoplasty is indicated.

7. Vyayojima: Similarly if one fragment of cut ear lobule is larger in dimension then another, then vyayojima type of otoplasty is indicated.

8. Kapat Sandhik: This type of otoplasty is usually suitable when one fragment of cut ear lobule is longer from proximal side and the second one is shorter.

9. Ardha Kapat Sandhik: Similarly Ardhakapt sandhik type of otoplasty is indicated when outer fragment of cut ear lobule is larger in dimension.

10. Aharya: When both the fragments of cut ear lobules are absent, at that time Aharya type of otoplasty is indicated.

Usually above 10 types of otoplasty are successful hence frequently used by Ancient Surgeon. If outer i.e. distal fragment of injured lobule is larger than stitch it to inside. Similarly when inner or proximal fragment of injured lobule is larger than stitch it to the outside so that smooth shape and fine outlook will achieve. ${ }^{7}$ When only one fragment of lobule is present which is broader, thicker and stable, in such case an incision is made in the proximal or inner side of the lobule, made thinner by dissecting from inside removing some soft tissue and then stitched to the inferior end of tragus; giving an appearance of natural ear lobule with fine texture and thickness.

Reconstructive Rhinoplasty described by Sushruta Sushruta in his first compendium verse 49 to 53 vividly described about the reconstructive Rhinoplasty. Reconstruction of lost nose (Rhinoplasty) is described here in case of nose is lost either by disease or in accident.
A leaf equal to the dimensions of the excised nose is taken. It is used to measure, the dimensions of the nose over the cheek. The skin flap from cheek (as measured) is then taken (remaining attached to donor site with a thin slip). The stump of nose is then stitched quickly with the help of a needle. After this two small (suitable with the shape of nostrils of the person) hollow stems of Ricinus communis are fitted at the nostrils. Position and shape of both nostrils is checked and the columellar process is joined and stitched. After this a powder of Pterocampus santalenus, Glycerrhiza glabra and "Rasot" (a crude extract of 'Barberis aristata) should be sprinkled over the operated area. Then the operated part should be covered with cotton pad or gauze and irrigated with sesame oil frequently.

\section{Post Operative measure}

After digestion of food ingested earlier, patient is ask to take the ghrita (Best Agni Deepak) and Virechana Karma is done after this.

\section{Dressing}

Apply honey and ghrita and cover with a gauze or cotton pad and tie with the bandage neither tight nor loose (sama bandha) and sparkle the clay powder over it (to fix) and take the patient for post operative care.

\section{Post Operative Care}

The patient should be instructed to save the pinna from any direct violence; and the patient should avoid day sleeping, heavy exercise, heavy diet, sexual inter course, direct heat and excessive speech etc.

\section{Reconstruction of cleft lip}

Injured lip or congenital cleft lip is also reconstructed by the same method as described by Sushruta in first compendium of Sushruta Samhita verse 16. The only differences that in this case the Ricinus communis stems are not used. The Vaidya who get skilled in this method's becoming Rajvaidya who can treat the king.

\section{Plastic Surgery in Middle Age}

Otoplasty, Rhinoplasty and cleft lip surgery are also mentioned in Ashtang Sangrah and Ashtang Hridaya. The only advancement that could be traced between this much time period is the thread used for stitching is found in Ashtang Sangraha other procedures are same as described by Sushruta. After opposing the flap to the stump of nose and joining properly, part is then stitched with silk thread.

\section{CONCLUSION}

Thus, plastic surgery is a very old science. It is however difficult to say when the plastic operations on man were performed. Primitive man knew how to do grafting in plants. This might have given him the idea of transferring tissue in man and animals. The necessity arose when one lost such parts of his/her body as the nose, where it has been a common form of injury in all periods of history. It became a social necessity to find a substitute for the lost nose. The development of plastic surgery is closely connected with the operative techniques used in the field know as Rhinoplasty. It may be noted that charak and 
Sushruta Samhita are translated in to Arabic and Persian about 800 AD. Since Arabic medicine became the chief authority for European medicine in $17^{\text {th }}$ Century. So Indians ideas have indirectly entered modern western medicine. British surgeons learned the art of rhinoplasty from Indians during British rule. After getting fresh impetus from India, plastic surgery has made great progress in the past two hundred years. In 1993 the $1^{\text {st }}$ International Congress of plastic surgery was held in Paris. Basically the task of plastic surgery is to restore the parts of the body destroyed or damaged by disease and injury. But in recent year cosmetic surgery as a beauty treatment has become very fashionable. Anyway, we should remember that the sources of plastic surgery are the Sushruta samhita and it was from India, the European learnt the technique of Rhinoplasty and Otoplasty.

\section{REFERENCES}

1. Arch Otolaryngology Head Neck Surg 2002; 128(3): 233235 http://dx.doi.org/10.1001/archotol.128.3.233

2. Rig-Veda (1-158, 4-6), 1-116.95, (1-117-19)

3. Acharya Sushruta. Sutrasthana 16/10 (Hindi Translation Vol.1). Sushruta Samhita, Kaviraja Ambikadutta Shastri, published by Chaukahmbha Sanskrit Sansthan Varanasi, Reprint; 2007. p. 66

4. Acharya Sushruta. Sutrasthana 16/16 (Hindi Translation Vol.1). Sushruta Samhita, Kaviraja Ambikadutta Shastri, published by Chaukahmbha Sanskrit Sansthan Varanasi, Reprint; 2007. p. 67

5. Acharya Sushruta. Sutrasthana 16/11 (Hindi Translation Vol.1). Sushruta Samhita, Kaviraja Ambikadutta Shastri, published by Chaukahmbha Sanskrit Sansthan Varanasi, Reprint; 2007. p. 66

6. Acharya Sushruta. Sutrasthana 16/14 (Hindi Translation Vol.1). Sushruta Samhita, Kaviraja Ambikadutta Shastri, published by Chaukahmbha Sanskrit Sansthan Varanasi, Reprint; 2007. p. 67

7. Acharya Sushruta. Sutrasthana 16/15 (Hindi Translation Vol.1). Sushruta Samhita, Kaviraja Ambikadutta Shastri, published by Chaukahmbha Sanskrit Sansthan Varanasi, Reprint; 2007. p. 67

Cite this article as:

Panigrahi, Hemanta Kumar. Origin of surgery: A history of exploration of plastic and reconstructive surgery. Int. J. Res. Ayurveda Pharm 2013;4(5):634-637 http://dx.doi.org/10.7897/2277-4343.04501 